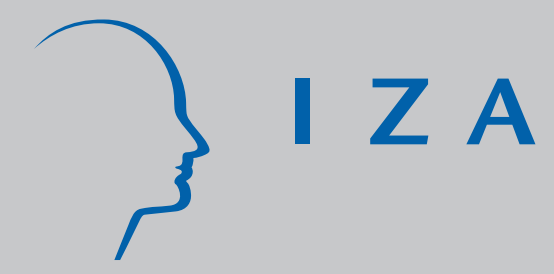

IZADP No. 1562

The Labour Market Effects of Alma Mater:

Evidence from Italy

Giorgio Brunello

Lorenzo Cappellari

April 2005 


\title{
The Labour Market Effects of Alma Mater: Evidence from Italy
}

\author{
Giorgio Brunello \\ University of Padova, CESifo \\ and IZA Bonn \\ Lorenzo Cappellari \\ Catholic University of Milan, CESifo, CHILD \\ and IZA Bonn
}

\author{
Discussion Paper No. 1562 \\ April 2005
}

IZA

\author{
P.O. Box 7240 \\ 53072 Bonn \\ Germany
}

\author{
Phone: +49-228-3894-0 \\ Fax: +49-228-3894-180 \\ Email: iza@iza.org
}

\begin{abstract}
Any opinions expressed here are those of the author(s) and not those of the institute. Research disseminated by IZA may include views on policy, but the institute itself takes no institutional policy positions.
\end{abstract}

The Institute for the Study of Labor (IZA) in Bonn is a local and virtual international research center and a place of communication between science, politics and business. IZA is an independent nonprofit company supported by Deutsche Post World Net. The center is associated with the University of Bonn and offers a stimulating research environment through its research networks, research support, and visitors and doctoral programs. IZA engages in (i) original and internationally competitive research in all fields of labor economics, (ii) development of policy concepts, and (iii) dissemination of research results and concepts to the interested public.

IZA Discussion Papers often represent preliminary work and are circulated to encourage discussion. Citation of such a paper should account for its provisional character. A revised version may be available directly from the author. 


\section{ABSTRACT}

\section{The Labour Market Effects of Alma Mater: Evidence from Italy*}

We use data from a nationally representative survey of Italian graduates to study whether Alma Mater matters for employment and earnings three years after graduation. We find that the attended college does matter, and that college related differences are substantial both among and within regions of the country. However, these differences are not large enough to trigger substantial mobility flows from poorly performing to better performing institutions. There is also evidence that going to a private university pays off at least in the early part of a career: the employment weighted college wage gains from going to a private college are close to 18 percent. Only part of this gain can be explained by the fact that private universities have lower pupil - teacher ratios than public institutions.

JEL Classification: J24

Keywords: college education, Italy

Corresponding author:

Giorgio Brunello

Università di Padova

Dipartimento di Scienze Economiche

Via del Santo 33

35100 Padova

Italy

Email: giorgio.brunello@unipd.it

\footnotetext{
* We are grateful to Daniele Checchi, Maria De Paola, Christian Dustmann, Francesca Gambarotto, Eliana La Ferrara, Paolo Ghinetti, Guglielmo Weber and the audience at seminars in Milan, Padova and at Workshop "Education and Training: Markets and Institutions" in Mannheim for comments, and to Marco Spaltro for research assistance. The econometric analysis in this paper was carried out at the Adele Laboratory, ISTAT, Rome. The usual disclaimer applies.
} 


\section{Introduction}

Does the attended college affect the earnings and employment prospects of graduates? This question is particularly important for those households sending their offspring to college and paying part of the cost, and for the government, which often runs universities and needs to know whether and why some institutions are delivering better outcomes than others.

Spurred by the interest on the quality of education, a recent literature has investigated the labour market effects of college quality, mainly but not exclusively in the US. Black and Smith, 2004, and Brand and Halaby, 2003, review the key contributions. The main focus in this literature has been on comparing elite versus non - elite colleges, and the degree of selectivity has been measured either with the average SAT score of the incoming freshmen in the US - or with the average A-level score of the intake of students - in the UK (see Chevalier and Gonlon, 2003). The basic finding of this literature is that college quality matters for labour market outcomes.

In this paper we investigate the Italian case and study the effect of the attended university on earnings and employment prospects three years after graduation. The Italian case is interesting. Compared to the experience of other developed countries, the system of Italian universities has resisted differentiation - in terms of recognized prestige or curriculum ${ }^{1}$. While selective admission criteria are not forbidden, they are not the standard practice of most public universities, which charge very low tuition fees to admitted students. Given this institutional framework, the natural expectation is that the college an individual has graduated from - her Alma Mater - should matter little for labour market performance.

Since we cannot measure unambiguously selectivity, we focus instead on college fixed effects, the public/private divide and on observable measures of college quality. We find that Alma Mater matters for the early labour market performance of Italian graduates, and that graduates of most universities located in the more developed Northern part of the country experience three

\footnotetext{
${ }^{1}$ Arum, Gamoran and Shavit, 2004, classify university systems into unitary, binary and stratified, and allocate the Italian system to the small club of unitary systems.
} 
years after graduation significantly higher employment weighted earnings than graduates from Southern universities.

In the absence of constraints to college choice, these significant interregional differences should be arbitraged away by the mobility of students from the South to the North. However, we find that such mobility is limited. On possible reason is liquidity constraints, but we find little evidence of their presence. Alternative explanations include regional cost differentials, which reduce the rate of return gap between the North and the South, and the possibility that the uncovered differences in returns are temporary.

We also find that graduating from a private university yields a 18 percent premium in terms of employment weighted earnings with respect to graduating from a public college. Measures of college quality and size go some but not all the way in explaining the private college premium. We speculate that additional factors are at play, especially for privileged individuals: private schools provide valuable network effects, and the value of these networks is higher for individuals with a good family background, because of the complementarity between family and school networks.

Our results have a number of interesting policy implications. First, we find that a 10 percent decrease in the pupil / teacher ratio should increase employment weighted college earnings by 2.4 percent. Therefore, reducing crowded classrooms is likely to improve the quality of graduates and increase private and social payoffs. Whether this increase is sufficient to compensate the costs of having a higher number of faculty remains an open question. Second, many commentators ${ }^{2}$ have argued that student mobility is an essential part of the much needed reform of the Italian higher education system. Our findings suggest that the actual dispersion of employment weighted earnings by college of graduation is not sufficient to trigger relevant inter-regional mobility flows. Unless these differentials increase or become more permanent, there is little hope that student mobility increases in a significant way in the near future.

\footnotetext{
${ }^{2}$ See for instance Perotti [2004].
} 
The paper is organized as follows. Section 2 introduces the data; Section 3 discusses the empirical approach; Section 4 presents the results. Conclusions follow.

\section{The Data}

The National Statistical Office (ISTAT) carries out on a regular basis a survey - the "Indagine statistica sull'inserimento professionale dei laureati" on the transition from college to work of a representative sample of Italian graduates. In the last available wave individuals who graduated in 1998 are interviewed three years after completion of the degree, in 2001. The interviewed sample corresponds to 16 percent of the population of graduates of 1998. The survey covers school curriculum, labour market experience in the three years after graduation, job search activities, household and individual information. We match these data with information on college quality disaggregated by field of study and provided by ISTAT for the academic year 1996- $7^{3}$.

The focus of our analysis is on the effects of the university the individual graduated from - her Alma Mater - on the probability of being employed three years after graduation and on her net monthly earnings in the job held at the time of the interview. Employment in the survey refers to all paid jobs, including training contracts ${ }^{4}$. About 4 percent of the currently employed are on a training contract - which includes post-graduate education. This percentage raises to close to 44 percent among those not currently working. Since the earnings in a training contract are likely to be rather far from normal earnings, we exclude individuals on a training scheme from our estimating sample.

\footnotetext{
${ }^{3}$ ISTAT, Lo stato dell'università, several issues. Since the publicly available micro-data do not include information on the university the interviewed individual graduated from, we carried out the matching at the ADELE ISTAT laboratory in Rome.

${ }^{4}$ The relevant question is: "Are you now - at the time of the survey - on a paid job? "Only a very small minority of those not currently employed were employed in the week before the interview. Since we do not have information on wages, we drop these individuals from the sample.
} 
Monthly earnings in 2001 are in euros and net of taxes and social security contributions ${ }^{5}$. Average earnings in the sample are 1142 euros per month, with a standard deviation of 414.9, and range from a minimum of $103,2 €$ to a maximum of $4131,6 €$. On the other hand, the average probability of being employed three years after graduation is 0.758 , so that more than 7 graduates out of 10 are employed at the time of the survey.

Table 1 shows average pay and employment probability by gender, type of college - public or private - and area where the college is located. On average, male graduates earn about 25 percent more than females, and are more likely to have a paid job three years after graduation. Having graduated from a private college yields a wage premium close to 10 percent, and a premium in the probability of employment around 15 percent. Finally, graduation from a college located in the Northwest yields a 20 percent wage premium and an almost 50 percent employment premium with respect to having graduated in a Southern college. The regional wage premium falls considerably from 20 to 8.3 if we compare individuals who graduated from a college in the Northwest and work in the same area with individuals who graduated in the South but work in the Northwest.

Table 1. Average earnings and employment probability by gender, type of college and college area

\begin{tabular}{l|cc}
\hline & $\begin{array}{c}\text { Average } \\
\text { monthly earnings }\end{array}$ & $\begin{array}{c}\text { Average } \\
\text { employment probability }\end{array}$ \\
\hline Male & 1267,8 & 0,823 \\
Female & 1027,4 & 0,693 \\
Private college & 1268,9 & 0,858 \\
Public college & 1132,2 & 0,743 \\
College located in Northwest Italy & 1230,7 & 0,865 \\
College located in Northeast I taly & 1133,7 & 0,823 \\
College located in Central Italy & 1117,3 & 0,723 \\
College located in Southern Italy & 1041,4 & 0,587 \\
\hline
\end{tabular}

Needless to say, the average values in Table 1 are affected by individual characteristics, the college and the field of study. Table 2 reports average

\footnotetext{
5 Earnings in the publicly available data are provided in brackets rather than as a continuous variable. All our computations based on continuous variables were carried out at the ADELE ISTAT laboratory in Rome.
} 
earnings and employment probabilities in seventeen fields of study, which correspond to different faculties. Average earnings are highest for graduates in Medicine, who face on the other hand among the lowest employment probability, and lowest for graduates in Foreign Languages. Figure 1 and Figure 2 show that both earnings and employment probabilities vary substantially with the college within each field of study. The within-field of study variation in earnings - measured by the coefficient of variation - is highest in Medicine, where a graduate from Verona and Padova earn per month close to 100 percent more than a graduate from Pisa and L'Aquila. Moreover, the average monthly earnings of a graduate in Economics from Bocconi University, a private institution, are about 60 percent higher than the earnings of a graduate in the same field from the University of Benevento, at the bottom of the list.

Table 2. Average earnings and employment probability by field of study

\begin{tabular}{l|cc}
\hline & Average monthly earnings & $\begin{array}{c}\text { Average } \\
\text { Employment probability }\end{array}$ \\
\hline Agricultural studies (AG) & 1112.1 & 0.821 \\
Architecture (AR) & 1109.1 & 0.775 \\
Economics and Business (EC) & 1224.7 & 0.833 \\
Pharmacy (PH) & 1007.5 & 0.528 \\
Chemistry (CH) & 1182.3 & 0.911 \\
Law (LA) & 1169.9 & 0.914 \\
Engineering (EN) & 1352.5 & 0.950 \\
Humanities (HU) & 947.5 & 0.628 \\
Foreign languages (FO) & 933.4 & 0.671 \\
Medicine (ME) & 1659.9 & 0.553 \\
Veterinary (VE) & 1089.6 & 0.702 \\
Psychology (PS) & 945.8 & 0.695 \\
Teachers college (TE) & 925.3 & 0.668 \\
Natural Sciences (SC) & 1099.4 & 0.776 \\
Political Science (PO) & 1154.8 & 0.825 \\
Statistics (ST) & 1198.0 & 0.915 \\
\hline Sociology (SO) & 1105.4 & 0.605 \\
\hline
\end{tabular}


Turning to employment probabilities, it is always the case that these are lowest for graduates of Southern colleges. For example, a graduate in Engineering from the University of Trieste has a probability of employment after three years close to 1 , compared to less than 0.6 for a graduate from Potenza, in the South.

Figure 1. Within field variation in average earnings

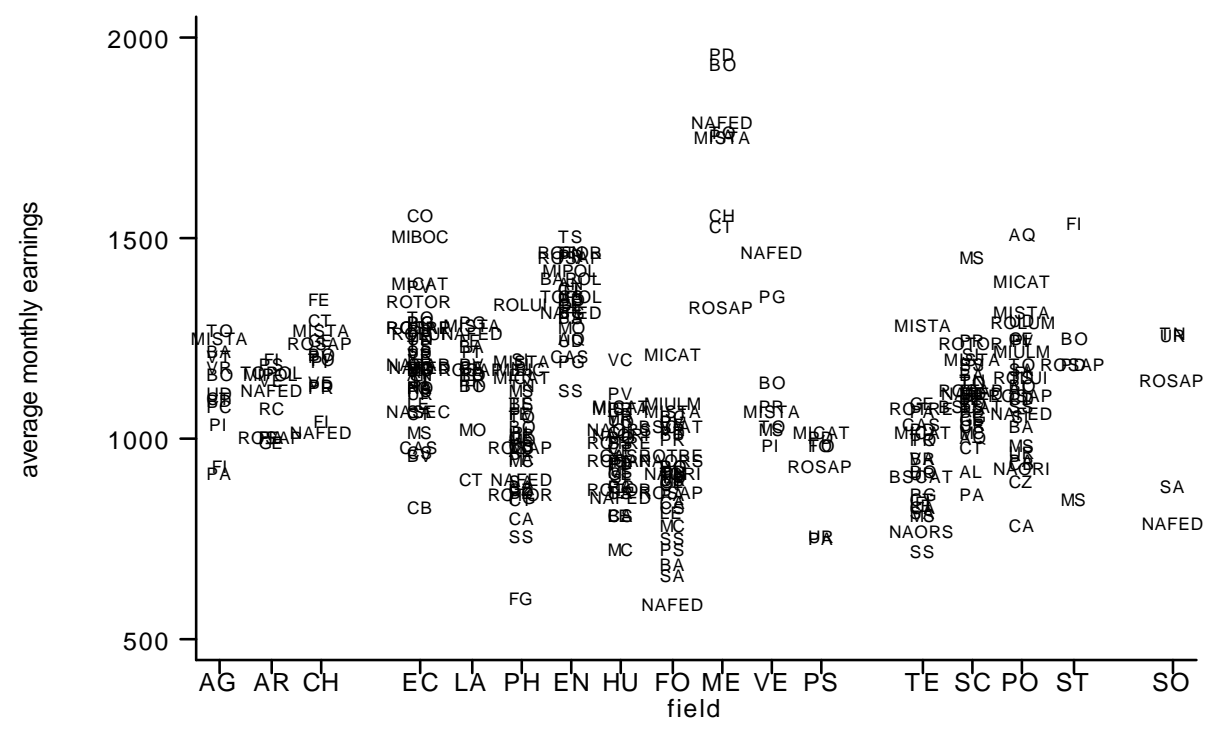

Note: see the legend in the Appendix

Figure 2. Within field of study variation in employment

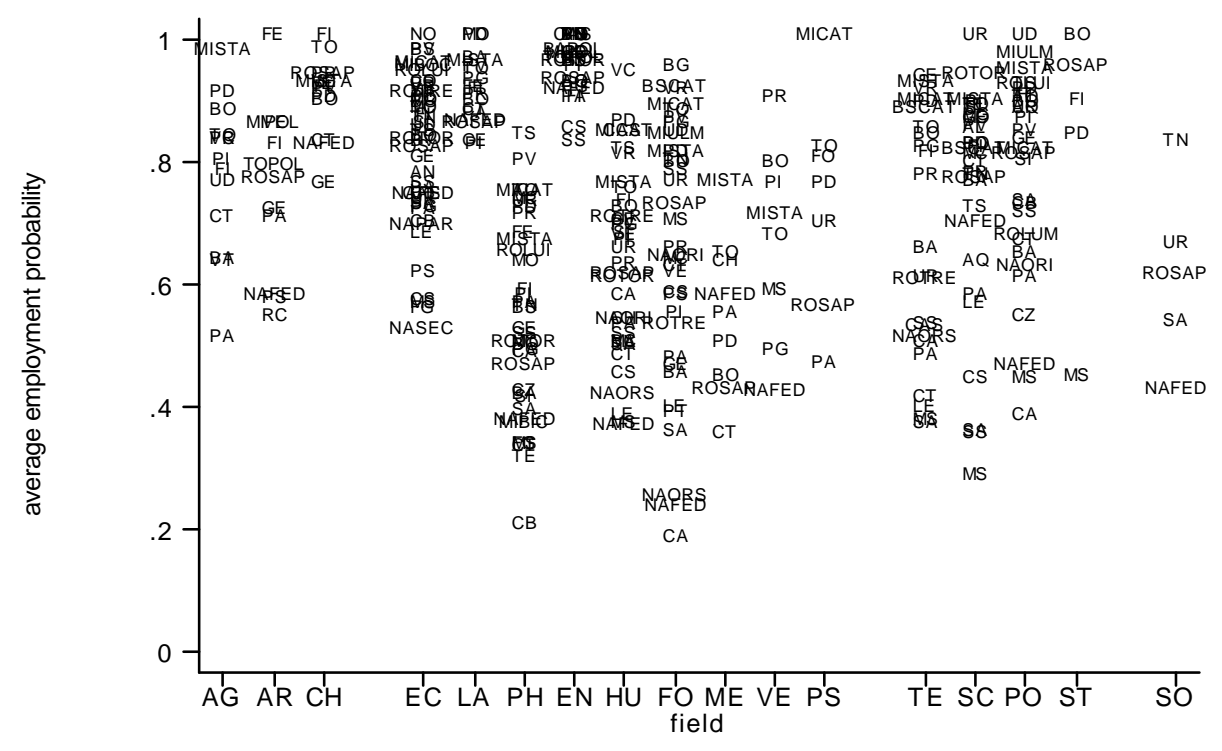

Note: see the legend in the Appendix 
Next, we compare the average earnings and employment probabilities of graduates of public and private colleges - by restricting attention to Economics, which include a few private universities. Figures 3 and 4 show that private colleges do better on average than public colleges, both for earnings and for employment. Some private universities, however, perform worse in terms of earnings and at least as well in terms of employment as top public institutions.

Figure 3. Average monthly earnings in public and private colleges - Economics

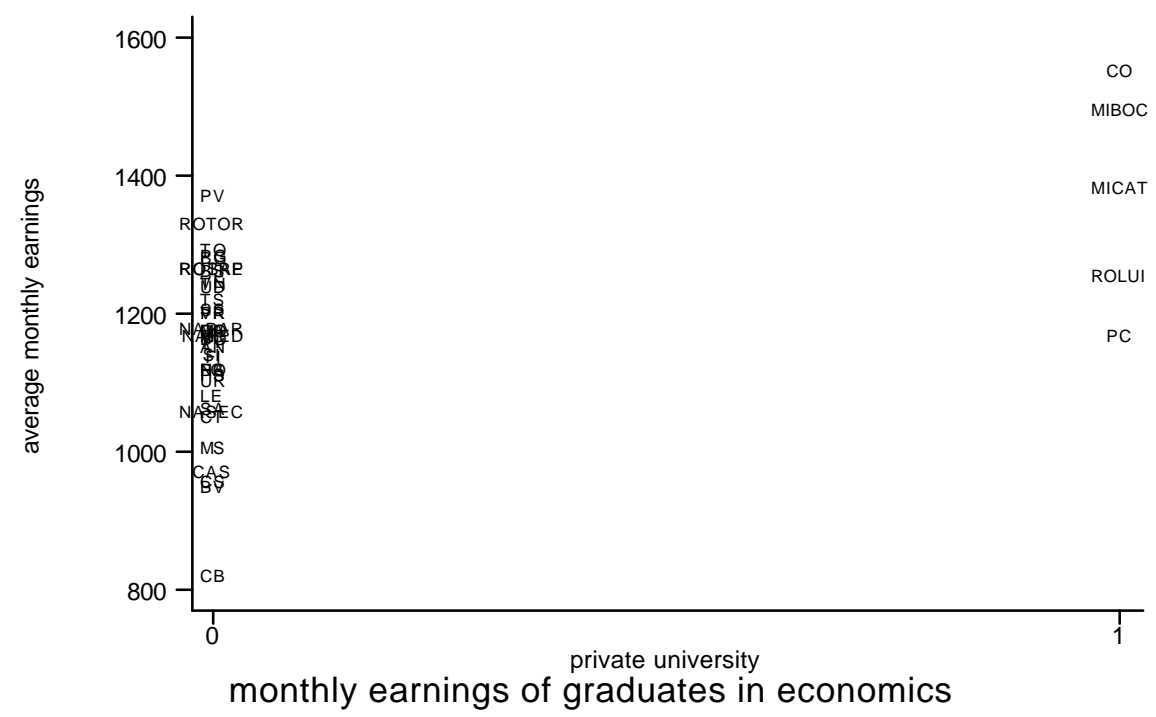

Note: see the legend in the Appendix

Figure 4. Average employment probability in public and private collegesEconomics

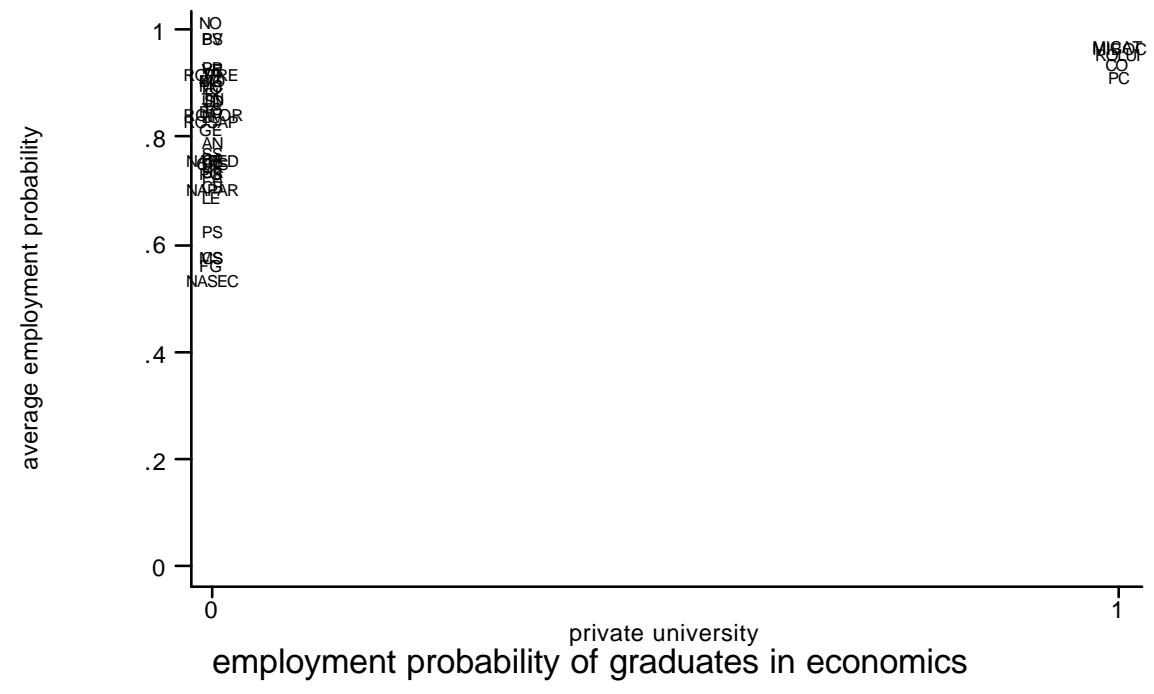

Note: see the legend in the Appendix 
For instance, the graduates of Roma Luiss, a private college, earn on average about the same as the graduates of Roma Tre and Roma La Sapienza, but slightly less than the graduates of Rome Tor Vergata, a public institution located in the same city.

Both private and public colleges generate heterogeneous outcomes in the labour market. Part of this heterogeneity could fade away over time, as graduates settle in their jobs, and part could depend on measurable differences in inputs and outputs. Table 3 illustrates some of these differences, separately for public and private colleges.

Table 3. Differences in inputs and outputs, by type of college

\begin{tabular}{l|cc}
\hline & Public college & Private college \\
\hline Year when the faculty was established & 1932 & 1958 \\
Student / teacher ratio & 41.69 & 25.78 \\
Number of students & 4605 & 3698 \\
Percentage of graduates over enrolled students & 7.54 & 11.76 \\
\hline & & \\
\hline
\end{tabular}

Note: the year of establishment is coded as 1800 if the college was established in 1800 or before.

The table shows that private universities tend to be younger, smaller, have a significantly lower ratio of students to teachers and a significantly higher percentage of graduates on enrolled students.

\section{Empirical strategy}

The recent literature on the estimation of the effects of college quality on earnings highlights a few issues inherent to such exercise. Specifically, Black and Smith, 2004, discuss the pitfalls that a standard log-wage regression could lead to, and how matching estimators can solve/mitigate those issues. First, there is the issue of selection on unobservables, omitted variable bias in the language of linear regression: as long as factors that influence both treatment receipt (in their case college quality) and the outcome (earnings) are omitted from the estimating model, resulting effects are biased and inconsistent. 
Second, there is the issue of the common support, multicollinearity in the language of linear regression: in order for the effect to be identified the variability of the treatment over the sample must not be already captured by other covariates in the model, which is achieved when there are cells defined by the intersection of the covariates in which both treated and non-treated individuals are observed. Black and Smith stress an important implication of this property: the effect estimated by a linear regression is identified nonparametrically only in the common support, while outside the common support it is a parametric projection of the effect estimated using observations in common support.

Third, and finally, they point to the issue of linear conditioning on observables, functional form misspecification in the language of linear regression: even if all the relevant personal attributes are controlled for, an omitted variable bias could emerge if they enter the estimating equation with an inappropriate functional form.

The Black and Smith approach is to resort to a (propensity score) matching estimator. As explained in their paper, such an approach: a) assumes that there is no selection on unobservables problem; b) '...does not solve the problem... (page 100)'; and c) solves the linear conditioning issue, because rather than assuming that the expected value of the outcome conditional on the observables is a linear function of the observables, it makes a fully non-parametric comparison of mean outcomes between treated and non-treated individuals in the common support.

In this paper we take a different and perhaps more standard estimating approach. Let the outcome of interest, $y_{i}$, be a linear function of the attended college-faculty cluster $\left(\mathrm{d}^{\mathrm{cf}}{ }_{\mathrm{i}}\right)$ and of observable attributes $\left(\mathrm{x}_{\mathrm{i}}\right)$

$$
\mathrm{y}_{\mathrm{i}}=\alpha+\Sigma_{\mathrm{f}} \Sigma_{\mathrm{c}} \mathrm{d}^{\mathrm{cf}}{ }_{\mathrm{i}} \theta^{\mathrm{cf}}+\mathrm{x}_{\mathrm{i}}{ }^{\prime} \gamma+\mathrm{u}_{\mathrm{i}} \quad \mathrm{i}(\mathrm{i}=1 \ldots \mathrm{N}),
$$

In our case $y_{i}$ is either the log of net monthly earnings or the individual latent propensity to be employed; we analyze the former using linear regression, whereas for the latter we assume normality of the error and use a probit 
regression. The vector of observables includes gender, region of employment, labour market experience, parental background in terms of occupation and education, the final graduation mark, the type of high school attended (whether generalist or technical/professional) and the marks reported in the high school graduation exam. Parental background and school performance before college capture unmeasured individual ability and self-selection effects. Importantly, we also include the interactions between parental education and occupations, on the one hand, and marks and school types, on the other. Therefore, we allow some of the regressors related to personal attributes to enter the model non-linearly, which attenuate the risks of misspecifying the functional form. As for the first problem discussed in Black and Smith, 2004, we assume, as they do, selection on observables, and specify a rather extended list of observables ${ }^{6}$.

The inclusion of 19 regional dummies - one for each region ${ }^{7}$ - captures local labor and product market effects and implies that the identification of the college by faculty effects is provided by those individuals who have gone to college in a region and are employed in another region. By using regional rather than provincial dummies we implicitly assume that local labor market conditions do not vary significantly within each region. Since one college per province is the general rule in Italy, this assumption is necessary and the inclusion of provincial rather than regional dummies is not feasible because it would capture in most of the cases the college effects we are interested in. Regression [1] is the first step in our procedure and allows us to predict logmonthly earnings and employment probability by college/faculty clusters. In the second step, we follow Card and Krueger, 1990, and analyze the determinants of college/faculty wage and employment effects. That is, we aggregate the data up to the college/faculty cluster level and estimate the economic impact of the college of graduation and college quality from such aggregated data. One reason for taking this route is that our measures of college quality are at the college-faculty level. It is the variation at this level

\footnotetext{
${ }^{6}$ In the employment case, the conditioning set excludes labour market experience and type of job, and the region of work is substituted with the region of birth.

${ }^{7}$ We pool tiny Val d'Aosta with Piemonte.
} 
that we exploit when estimating college quality effects. Moreover, this approach allows us to average out individual-level unobserved heterogeneity within clusters. Finally, due to the rich set of controls included in the first step regression, aggregated measures of economic outcomes will not reflect individual level heterogeneity between the cells that we capture with the interactions of parental background and individual ability indicators available in the data.

Specifically, let $q_{\mathrm{cf}}$ be the estimate of $\theta^{\text {cf }}$ from the earnings or employment equation ${ }^{8}$. We call these estimates the college by field of study wage or employment effects. In the second step of our procedure, we estimate

$$
q_{c f}=\Sigma_{j} \phi_{j} f_{c f}^{j}+\Sigma_{k} \chi_{k} C_{f c}^{k}+\beta^{\prime} z_{c f}+\varepsilon_{c f}
$$

where $f^{j}, j=1 . . F$, is a set of faculty dummies, $c^{k}, k=1 \ldots C$ is a set of college dummies, while $z$ is a vector of variables measuring college quality. Coefficients associated to the dummy variables in [2] therefore capture the average earnings or employment effect associated to each college or faculty These second step estimates are based on Weighted Least Squares, using weights proportional to the (inverse) of $\operatorname{var}\left(q^{\text {cf }}\right)$ estimated from [1], to account for the fact that our dependent variables are estimates from the first stage. Moreover, we get around to the fact that employment effects are bounded in the $(0,1)$ interval by using a Box-Cox transformation.

Human capital theory suggests that educational choice is driven by expected returns. Therefore, an interesting measure of labour market performance three years after graduation is the employment weighted wage effect. Let $e_{c f}$ be the average employment probability and $w_{c f}$ be the average earnings in a given college-faculty cluster: expected earnings in the cluster are therefore $\mathrm{ew}_{\mathrm{cf}}=\mathrm{e}_{\mathrm{cf}} \mathrm{w}_{\mathrm{cf}}$ which can be expressed in $\operatorname{logs}$ as $\log \left(\mathrm{e}_{\mathrm{cf}}\right)+\log \left(\mathrm{w}_{\mathrm{cf}}\right)$, a quantity that we can compute (together with its variance) from our first stage

\footnotetext{
${ }^{8}$ In the case of employment, we transform the estimated coefficients associated with college-faculty cluster dummies into probabilities by using the standard normal distribution and by evaluating all the other regressors at their sample means.
} 
regression, and use as an additional outcome in the second stage WLS regression. This variable will play a prominent role in the discussion below.

\section{Results}

In the first step regressions reported in the Appendix we use the full sample consisting of more than 10 thousand graduates and fit log individual earnings and employment probabilities on 411 college by field of study dummies, individual experience, experience squared, number of siblings, cohort of birth dummies, type of job (whether the current job is part time or full time), dummies for additional years in college after the required years, dummies for the region where the current job is located, dummies for the number of siblings, individual college graduation marks - relative to the highest attainable mark, interactions between dummies for the type of school before college and dummies for ranges of graduating marks in upper secondary education, and family background - measured by a set of interactions of the education and the occupation of each parent when the individual was 14 years of age. By adding close to 120 controls for family background and school performance before college, we expect to capture unobserved individual ability, which affects earnings as well as selection into employment.

As mentioned in the previous section, the identification of college by faculty effects relies on the presence of a significant number of movers, who study in a region and work in another region. It turns out that slightly more than 26 percent of the close to 10 thousand individuals in our sample consists of movers.

\subsection{College effects on wages and employment}

We interpret the estimated coefficients of the 411 dummies, as the impacts of college and field of study on individual earnings and employment three years after graduation. Under the assumption that individual ability has 
been adequately captured by our first step controls, these estimates are consistent ${ }^{9}$.

The region of employment three years after graduation does not necessarily coincide with the region where the college was located, as individuals migrate to the areas of the country where they can locate better matches. The presence of these movers in our data is key to implement our econometric methodology. Table 4 illustrates the mobility flows across four macro areas, North-West, North-East, Centre and South, which group the 19 regions of the country. As expected, individuals completing a degree in the Centre or in the South are more likely than individuals in the North to relocate and work in another macro-area, typically the North West, where many college jobs are located ${ }^{10}$. In spite of these mobility flows, the percentage of individuals who currently work in the same area where they went to college is close to three quarters of the population of graduates. ${ }^{11}$

Table 4. Mobility flows among the four macro areas of Italy

\begin{tabular}{l|cccc}
\hline & $\begin{array}{c}\text { Employment } \\
\text { North West }\end{array}$ & $\begin{array}{l}\text { Employment } \\
\text { North East }\end{array}$ & $\begin{array}{l}\text { Employment } \\
\text { Centre }\end{array}$ & $\begin{array}{l}\text { Employment } \\
\text { South }\end{array}$ \\
\hline College North West & 93.52 & 3.47 & 1.65 & 1.36 \\
College North East & 12.30 & 81.87 & 3.86 & 1.97 \\
College Centre & 6.95 & 3.95 & 75.91 & 13.18 \\
College South & 9.17 & 3.34 & 6.87 & 80.62 \\
\hline
\end{tabular}

Note: the numbers in the table are percentages, which add up to 100 by row.

We disentangle the contributions of the field of study and the university to the wage and employment effects by regressing the estimated net effects on field of study and college dummies - see equation [2] above. In order to

\footnotetext{
${ }^{9}$ These are net impacts because the college and field of study can affect some of the controls, such as labour market experience, performance in college, type of job, region where the job is located and actual time to complete the degree. ${ }^{10}$ The North-East of the country is dominated by small and medium firms operating in the manufacturing sector, with a limited demand for college labour.

${ }^{11}$ It is worth noting that the North-East is a net exporter of college graduates towards the North-West, at least in relative terms. Part of this finding may reflect return migration: while almost 8 percent of natives from the North-West go to college in the North-East, the figures halve when considering the opposite flux. Still, the finding can be seen as a symptom of the different productive structure in the two areas, dominated by small manufacturing firms in the NorthEast, and by large enterprises in manufacturing and banking in the North-West, leading to a different structure of the demand for skills.
} 
have sufficient observations for each university, we restrict our attention to the institutions with at least three faculties.

The college dummies in these second step regressions measure the impact of each university on earnings and employment probabilities, conditional on the field of choice and on the individual effects controlled in the first stage. In Figure 5 we report these dummies for earnings and employment probabilities. For ease of interpretation, we normalize the estimated coefficients by setting their minimum values to $1^{12}$.

Figure 5. Wage and employment effects, by college

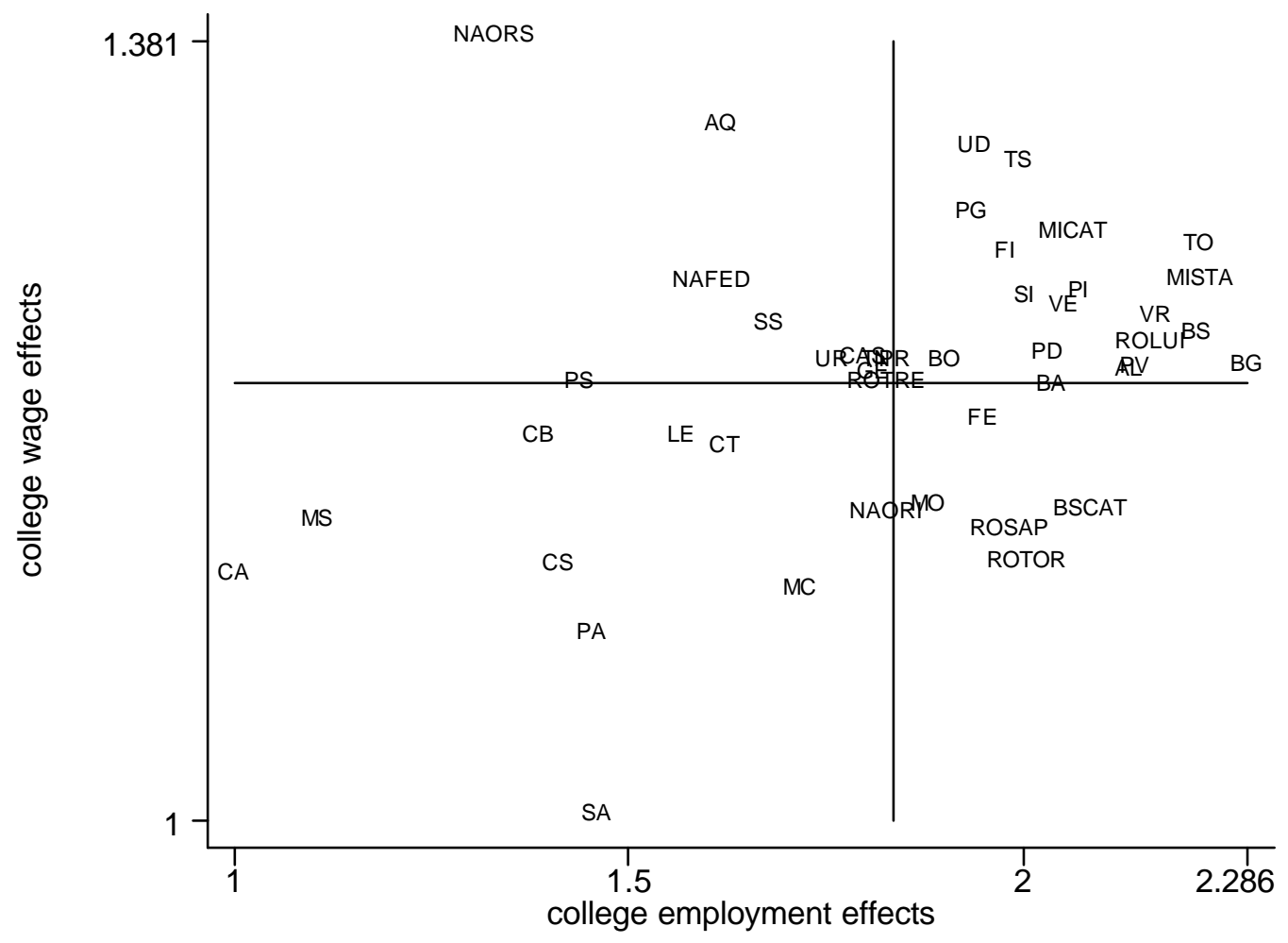

Note: see the legend in the Appendix. The horizontal and vertical lines are the sample means of the variables in the relevant axis

The figure shows that employment and wage effects vary considerably across universities: earnings three years after graduation are more than 35 percent higher for the graduates of Napoli Sant'Orsola (NAORS) - a private college - than for the graduates of Salerno (SA). The gap is much higher in terms of employment probabilities, which are more than 2 times as large for

\footnotetext{
${ }^{12}$ The second step regressions are presented in the Appendix
} 
the graduates of Bergamo (BG) than for the graduates of Cagliari (CA $)^{13}$.

Since the simple comparison of college wage effects is likely to be a misleading indicator of labour market performance, because of the differences in the probability of employment, we compute employment weighted college wage effects and plot them in Figure 6 according to the region where the college is located.

Figure 6. Employment weighted wage effects, by college and region where the college is located

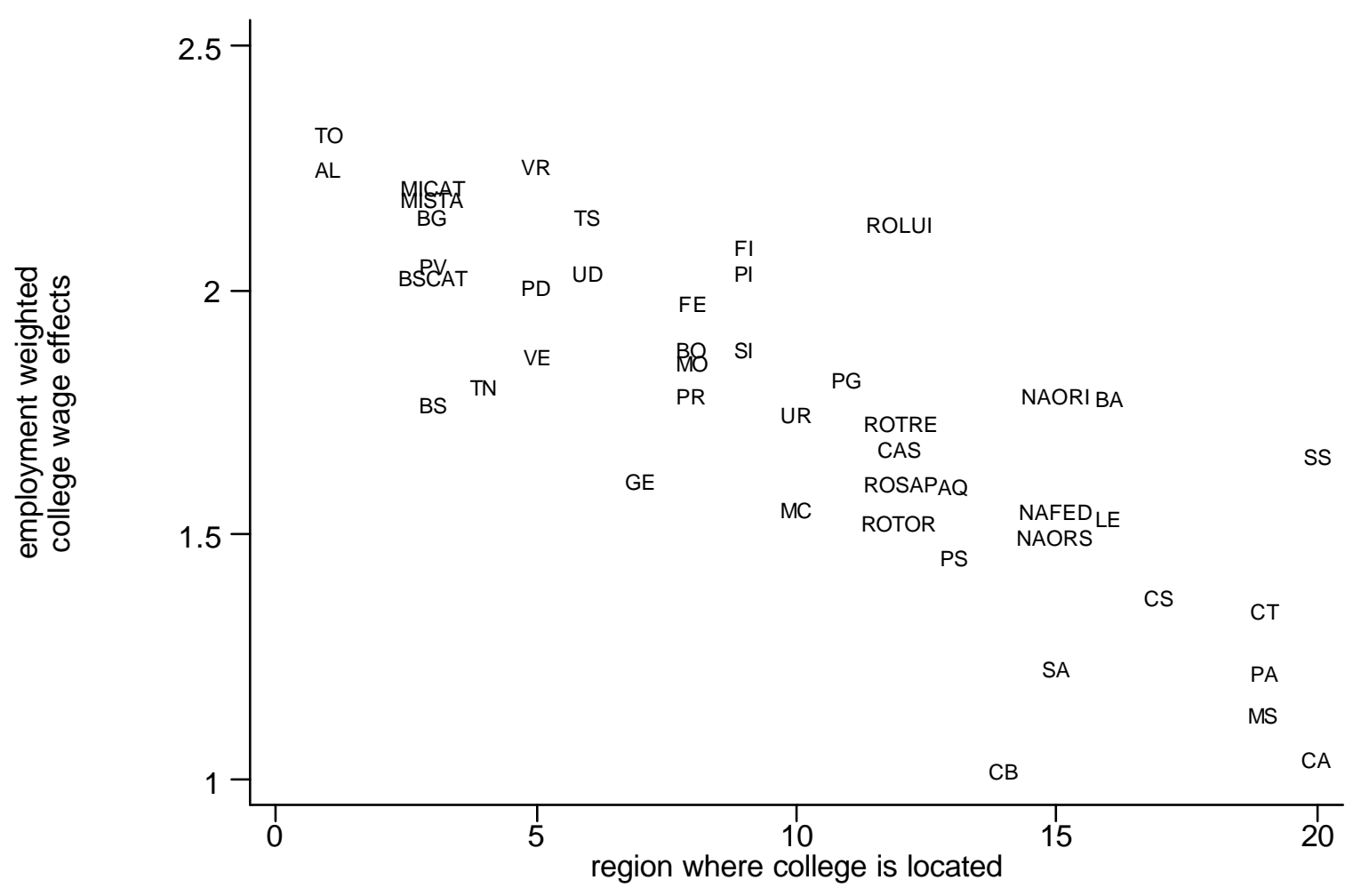

Note: the legend in the Appendix.

The figure shows that these effects are significantly higher for the graduates of many colleges located in the North of the country than for the graduates of most Southern colleges: the difference between the highest (Torino - TO) and the lowest college effect (Cagliari - CA) is close to 130 percent - and statistically significant. There are important exceptions, however. For instance, the graduates of Bari University (BA) - in the South have higher weighted earnings than the graduates of Genova (GE) - in the

\footnotetext{
${ }^{13}$ All these gaps are statistically significant at the 5 percent level of confidence
} 
North. There is also a significant difference in the weighted earnings of the graduates of the largest universities in Rome - La Sapienza (ROSAP) and Tor Vergata (ROTOR) - and the largest colleges in Milan - Statale (MISTA) and Cattolica (MICAT). For instance, male graduates from Tor Vergata earn in weighted terms three years after graduation close to 44 percent less than graduates from Milano Statale - and the gap is statistically significant.

One might object that the uncovered inter-regional differences reflect local labour market rather than college differences. In the first stage, however, we have explicitly controlled for local labour market effects by adding to the regressions regional dummies for the region where the job is located. To better illustrate the point, we re-estimate first stage regressions by omitting regional labour market dummies. The second step employment weighted wage effects - gross of local labour market effects - are shown in Figure 7. As expected, inter-regional gaps widen considerably, and the highest employment weighted college wage effects are registered now in Lombardy and in part of the NorthEast, the best performing economic areas of the country.

Sharp differences occur not only between universities located in distant regions, but also within regions. In Lombardy, for instance, there is a 22 percent premium from studying in Milano Statale (MISTA) rather than in Brescia (BS). An even larger gap occurs between the universities of Sassari (SS) and Cagliari (CA) in Sardinia. We stress that these differences need not reflect exclusively college effects but could also depend on differences in local labor market performance within regions.

If students were perfectly mobile across universities, and the private costs of graduating from each institution were homogeneous across the country, we would expect these large differences in college - specific labour market returns to be washed away by arbitrage activities. Mobility of university students, however, is limited. Our survey provides information both on the region of residence before going to college and on the region where the college is located. 
Figure 7. Employment weighted wage effects, by college and region where the college is located. Gross of local labour market effects.

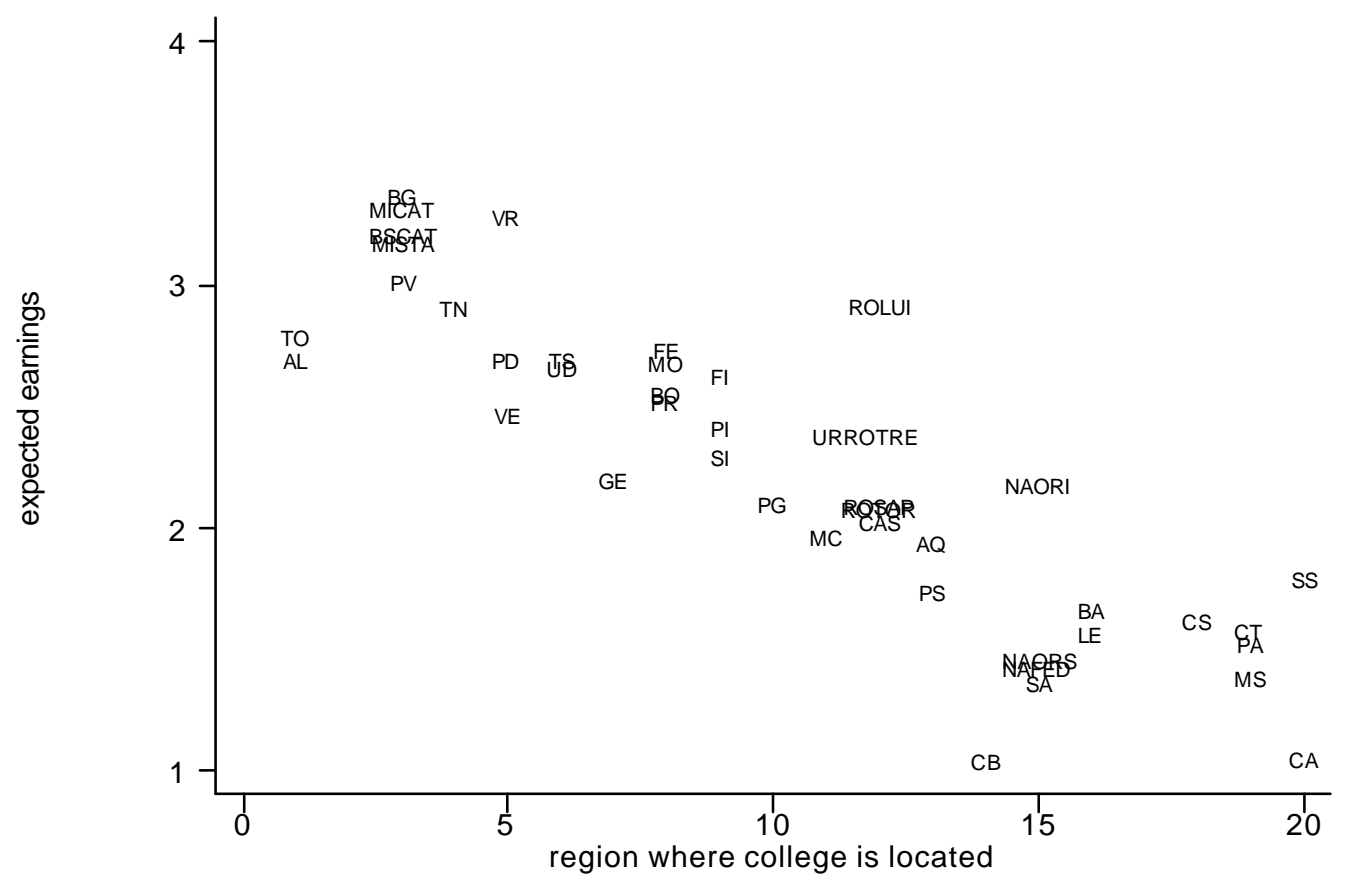

As shown by Table 5, there is very little mobility across macro-regions, not only in the Northern and Central areas, where many better performing universities are located, but also in the South, where universities are among the worst performing in the sample. More in detail, students who resided in the South before college either remain there for college $(73.5 \%)$ or move to the nearby Centre (18.8\%): less than $8 \%$ move to the North. However, these numbers cover some interesting heterogeneity within macro-areas. In the South, for instance, the percentage of students remaining in their region to go to college is higher than 80 percent in Sicily and Sardinia and close to 40 percent in Calabria, in spite of the fact that the employment weighted college wage effects associated to the University of Calabria (CS) are about the same if not higher than those associated to Sicilian universities (Palermo - PA Messina - MS - and Catania - CT).

How do we explain the observed limited mobility flows between macroareas in the presence of substantial differences in employment weighted college wage effects? Since most universities do not restrict admissions by 
applying numerus clausus ${ }^{14}$, the explanation must rely on the demand for college education. One natural possibility is that Southern students are restrained from enrolling in Northern colleges because of liquidity constraints.

Table 5. Mobility flows among the four macro areas of Italy, before college and during college

\begin{tabular}{l|cccc}
\hline & College & College \\
North West & North East & $\begin{array}{c}\text { College } \\
\text { Centre }\end{array}$ & $\begin{array}{c}\text { College } \\
\text { South }\end{array}$ \\
\hline Before College North West & 90.78 & 7.39 & 1.52 & 0.30 \\
Before College North East & 3.79 & 93.41 & 2.50 & 0.31 \\
Before College Centre & 0.88 & 4.79 & 93.69 & 0.64 \\
Before College South & 3.56 & 4.04 & 18.86 & 73.54 \\
\hline
\end{tabular}

Note: the numbers in the table are percentages, which add up to 100 by row.

If liquidity constraints had played a significant role in hampering the mobility of students from the South to the North, we would expect to find that inter-regional mobility is much lower for students belonging to less educated and less wealthy households. Surprisingly enough, this is not the case. If we replicate Table 5 separately for individuals with "good" and "poor" family background at age 14 - good background being defined when the father was an entrepreneur, a manager, a high ranked director, a teacher or a high ranked white collar, and bad background when the father was in a low paying occupation - there is no difference worth noticing - see Table 6 below.

The percentage of students in our dataset residing in the South who went to college in the South is $\mathbf{7 2 . 9 9}$ percent if from a good family background and 74.12 percent if from a bad background. On the other hand, the percentage of students residing in the South before college who moved to the North for college is 8.22 among those with good background and 6.94 percent among those with bad background. These differences remain small even when we measure background with parental education ${ }^{15}$.

\footnotetext{
${ }^{14}$ With a few exceptions, numerus clausus in Italy is restricted to specific fields - such as Medicine - and to newly established faculties.

${ }^{15}$ Results available from the authors upon request.
} 
Table 6. Mobility flows among the four macro areas of Italy, before college and during college.

Good bakground

\begin{tabular}{l|cccc}
\hline & College & College & College & College \\
& North West & North East & Centre & South \\
\hline Before College North West & 91.37 & 6.77 & 1.55 & 0.31 \\
Before College North East & 4.49 & 92.50 & 2.73 & 0.28 \\
Before College Centre & 1.15 & 4.64 & 93.48 & 0.73 \\
Before College South & 3.99 & 4.23 & 18.79 & 72.99 \\
\hline & \multicolumn{5}{|c}{} \\
\hline Bad background & College & College & College & College \\
\hline & North West & North East & Centre & South \\
\hline Before College North West & 90.06 & 8.17 & 1.49 & 0.29 \\
Before College North East & 2.97 & 94.46 & 2.24 & 0.33 \\
Before College Centre & 0.53 & 4.99 & 93.45 & 0.53 \\
Before College South & 3.10 & 3.84 & 18.94 & 74.12 \\
\hline
\end{tabular}

An alternative and we believe more plausible explanation of the limited mobility flows is that Northern colleges provide higher (expected) returns but at a higher cost, and that the internal rate of return to going to college does not differ significantly across macro-areas. There are three pieces of evidence favouring this explanation. First, tuition is higher in the North. Even though fees are not high by international standards, Northern colleges have used to a much larger extent than other universities in the country the opportunity to raise tuition in the second part of the 1990s above the centrally established ceiling (Law 122/94). This and the endogenous selection of students to college have implied that average tuition in 1995 was about 50 percent higher in Northern than in Southern public universities - $511 €$ versus $326 €$ at current prices (see Silvestri et al, 1996). Second, both opportunity and living costs including housing - are higher in the North. A recent survey of living costs in a sample of Italian universities has shown that in 2000 the annual cost inclusive of rent, transportation and food - of going to a university located in a different region was $6135 €$ in Pavia, $5866 €$ in Venice - both in the North, and $4668 €$ and $5402 €$ in the Southern cities of Cagliari and Napoli 
respectively, with a North - South gap close to about 30 percent (see Catalano and Fiegna, 2003).

Last but not least, the observed employment weighted college wage gaps three years after graduation could be temporary effects, which are washed away over time, as individuals settle down in the labour market and in permanent jobs. Evidence that the effects of college quality on earnings and employment probabilities wane over labour market careers is discussed by Warren, Hauser and Sheridan, 2002, and Brand and Halaby, 2003, for the US. Employers use credentials, including college quality, as a signal of skills at labour market entry, but as individuals age this signal loses importance relative to other sources of information, such as direct screening. Since mobility is triggered by expected differences in lifetime earnings profiles, university - specific temporary differences may be not sufficient to reallocate enrolment from the South to the North in the presence of cost differentials.

Support for this explanation comes from the 2002 wave of the Survey on the Income and Wealth of Italian Households (SHIW), carried out by the Bank of Italy, which includes information on the college of graduation. The sample of graduates is much smaller than the one we are using in this paper, but has the advantage of covering individuals of different age rather than only labour market entrants. We define a dummy for the young - aged from 25 to 34 and for the adult - aged from 35 to 55 , and regress both monthly earnings and employment propensities on individual controls, area of residence, field of study dummies and age dummies. We also interact both age group dummy with a dummy equal to 1 if the college of graduation was located in the North and to zero otherwise. Our key results are presented in Table $7^{16}$.

They show that monthly earnings do not differ in a significant way with the area where the college of graduation was located. Employment propensities, however, differ, because the young age group from Northern colleges enjoys a significantly higher probability of employment. More

\footnotetext{
${ }^{16}$ These regressions consider only employees, because the self-reported earnings of professionals are notoriously unreliable. Notice however that results do not change significantly if professionals are added to the sample. The results are available from the authors upon request.
} 
importantly for our purposes, however, is the finding that this relative advantage disappears among adults.

Table 7. Monthly wages and employment probabilities, by age group and region where the college is located. Weighted least squares

\begin{tabular}{l|cc}
\hline & Monthly wages & $\begin{array}{l}\text { Employment } \\
\text { probabilities }\end{array}$ \\
\hline Young * College North & $.129(.117)$ & $.751^{* *}(.312)$ \\
Adult & $.339 * * *(.091)$ & $1.475 * * *(.214)$ \\
Adult * College North & $.044(.082)$ & $.430(.351)$ \\
\hline Nobs & 518 & 870 \\
\hline
\end{tabular}

Note: each regression includes gender, region of residence and field of study dummies. The wage regression also includes a part-time dummy. The young age group in the Centre and South in the baseline. One, two and three stars for coefficients statistically significant at the 10, 5 and 1 percent level of confidence. Heteroskedasticity consistent standard errors.

This alternative explanation - based on cost differentials and on the fact that differentials in returns are likely to be temporary, goes some of the way also in explaining limited mobility within macro-areas. While economic considerations certainly play a role, historical, social and cultural factors also matter. For instance, the fact that college students from Calabria are much more mobile than students from Sicily does not seem to depend on expected earnings differentials. An important additional reason is that the largest university in the former region was established fairly recently, in the seventies. Before that, students from Calabria had to move elsewhere to study, and moving for college education was part of the social custom, contrary to the Sicilian experience, where universities where established in the nineteenth century.

\subsection{Private and public universities}

Why do earnings and employment probabilities three years after graduation vary depending on the attended college? The natural answer is that colleges differ in quality, and that this quality is priced by the labour market. One important dimension of college quality is whether the university is public 
or private. We investigate this dimension by replacing the college dummies in the second step regression either with a dummy equal to 1 if the university is private and to zero otherwise or with the interactions of this dummy with field of study dummies. By using interactions, we allow the effects of the private college dummy to vary with the field of study ${ }^{17}$. These effects can be identified because there is within-field variation in college status - either public or private. Table 8 presents the results separately for earnings, employment probabilities (Box Cox transformations) and employment weighted earnings.

Table 8. The effects of private universities on earnings and employment. WLS estimates

\begin{tabular}{|c|c|c|c|c|c|c|}
\hline $\begin{array}{l}\text { Private } \\
\text { college } \\
\text { dummies }\end{array}$ & Earnings & Earnings & Employment & Employment & $\begin{array}{c}\text { Employment } \\
\text { weighted } \\
\text { earnings }\end{array}$ & $\begin{array}{c}\text { Employment } \\
\text { weighted } \\
\text { earnings }\end{array}$ \\
\hline $\begin{array}{l}\text { Private } \\
\text { universities }\end{array}$ & $\begin{array}{c}.074 * * * \\
(.023)\end{array}$ & & $\begin{array}{c}.381 * * * \\
(.194) \\
.046\end{array}$ & & $\begin{array}{c}.180 * * \\
(.070)\end{array}$ & \\
\hline Economics & & $\begin{array}{l}.033 \\
(.038)\end{array}$ & & $\begin{array}{c}.622 * * * \\
(.257) \\
.069\end{array}$ & & $\begin{array}{c}.190 * * * \\
(.049)\end{array}$ \\
\hline Law & & $\begin{array}{c}.173 * * * \\
(.040)\end{array}$ & & $\begin{array}{c}.650 * * * \\
(.220) \\
.072\end{array}$ & & $\begin{array}{c}.540 * * * \\
(.078)\end{array}$ \\
\hline Humanities & & $\begin{array}{l}.087 * * \\
(.036)\end{array}$ & & $\begin{array}{l}.181 \\
(.344) \\
.023\end{array}$ & & $\begin{array}{l}.101 \\
(.108)\end{array}$ \\
\hline $\begin{array}{l}\text { Natural } \\
\text { Sciences }\end{array}$ & & $\begin{array}{l}.006 \\
(.055)\end{array}$ & & $\begin{array}{c}-.201 \\
(.239) \\
.029\end{array}$ & & $\begin{array}{l}.159 \\
(.108)\end{array}$ \\
\hline $\begin{array}{l}\text { Political } \\
\text { Science }\end{array}$ & & $\begin{array}{l}.047 \\
(.071)\end{array}$ & & $\begin{array}{l}.696 \\
(.482) \\
.076\end{array}$ & & $\begin{array}{l}.230 \\
(.123)\end{array}$ \\
\hline $\begin{array}{l}\text { Nobs } \\
\text { R Squared }\end{array}$ & $\begin{array}{l}362 \\
.499\end{array}$ & $\begin{array}{l}362 \\
.502\end{array}$ & $\begin{array}{r}341 \\
.398 \\
\end{array}$ & $\begin{array}{l}341 \\
.403 \\
\end{array}$ & $\begin{array}{l}341 \\
.381 \\
\end{array}$ & $\begin{array}{l}341 \\
.387 \\
\end{array}$ \\
\hline
\end{tabular}

We find that going to a private university has a positive and statistically significant effect. Since the wage effects are estimated from a first step log earnings equation, we can interpret the estimated coefficient attached to the private college dummy as the percentage change in earnings associated to graduating from a private college. To ease interpretation, coefficients on (Box-

\footnotetext{
${ }^{17}$ Notice that there are some fields of study - Engineering for example - which are only available in public universities. We pool together some fields - Psychology, Foreign Languages and Education with Humanities, Agricultural Studies with Natural Sciences - in order to have a sufficient number of observations in the second step estimation.
} 
Cox) employment effects are complemented by the implied effects on employed probabilities, which is the third number in each cell. It turns out that going to a private university increases employment weighted earnings three years after graduation by close to 18 percent, a significant effect. Behind the average effect there is substantial heterogeneity: the graduates of private universities in the fields of Law and Economics earn respectively close to 50 and 20 percent more than graduates of public colleges in the same fields. On the other hand, the graduates in the Humanities and Natural Sciences do not gain significantly from going to a private college.

Table 9 presents the results of second step regressions with private college dummies, conditional on controls for the field of study. There are 9 private universities in our sample of 68 universities, for which we have second step estimates of wage and employment effects.

Table 9. The effects of private college dummies on earnings and employment. WLS estimates.

\begin{tabular}{|c|c|c|c|}
\hline Private college dummies & Earnings & Employment & $\begin{array}{c}\text { Employment } \\
\text { weighted earnings }\end{array}$ \\
\hline Piacenza & $\begin{array}{l}-.020 \\
(.044)\end{array}$ & $\begin{array}{l}-0.118 \\
(.311) \\
-.017\end{array}$ & $\begin{array}{l}.101 \\
(.107)\end{array}$ \\
\hline Roma Luiss & $\begin{array}{l}.039 \\
(.074)\end{array}$ & $\begin{array}{c}0.833^{* * *} * \\
(.157) \\
.086\end{array}$ & $\begin{array}{l}.335^{* * *} \\
(.109)\end{array}$ \\
\hline Milano Bocconi & $\begin{array}{l}.092 * * * \\
(.011)\end{array}$ & $\begin{array}{c}.843^{* * *} \\
(.209) \\
.087\end{array}$ & $\begin{array}{c}.278 * * * \\
(.026)\end{array}$ \\
\hline Milano Cattolica & $\begin{array}{l}.080 * * * \\
(.023)\end{array}$ & $\begin{array}{c}.481^{* *} \\
(.218) \\
.056\end{array}$ & $\begin{array}{l}.347 * * * \\
(.058)\end{array}$ \\
\hline Castellanza & $\begin{array}{l}.134 * * * \\
(.011)\end{array}$ & $\begin{array}{c}.379 * * * \\
(.209) \\
.046\end{array}$ & $\begin{array}{l}.281 * * * \\
(.026)\end{array}$ \\
\hline MIlano IULM & $\begin{array}{c}.080 * * \\
(.036)\end{array}$ & $\begin{array}{c}1.419 * * * \\
(.355) \\
.120\end{array}$ & $\begin{array}{l}.433 * * * \\
(.057)\end{array}$ \\
\hline Napoli Sant'Orsola & $\begin{array}{l}.130 * * * \\
(.045)\end{array}$ & $\begin{array}{c}-.928 * * * \\
(.228) \\
-.169\end{array}$ & $\begin{array}{c}-.064 * * * \\
(.108)\end{array}$ \\
\hline Brescia Cattolica & $\begin{array}{l}-.037 \\
(.057)\end{array}$ & $\begin{array}{c}.460 * * \\
(.223) \\
.054\end{array}$ & $\begin{array}{l}.223 * * * \\
(.071)\end{array}$ \\
\hline Roma LUMSA & $\begin{array}{l}.131 * * * \\
(.035)\end{array}$ & $\begin{array}{c}-.877 * * * \\
(.211) \\
-.158\end{array}$ & $\begin{array}{l}-.117 \\
(.104)\end{array}$ \\
\hline $\begin{array}{l}\text { Nobs } \\
\text { R Squared }\end{array}$ & $\begin{array}{l}362 \\
.505\end{array}$ & $\begin{array}{l}341 \\
.422\end{array}$ & $\begin{array}{l}341 \\
.392\end{array}$ \\
\hline
\end{tabular}


We find that employment weighted earnings are significantly higher for the graduates of private universities, with the exception of Piacenza, Roma LUMSA and Napoli Sant'Orsola. The size of the gain associated to going to a private college is significant and close to or above 30 percent in the private universities of Milan and Roma Luiss.

\subsection{College quality}

Is the difference made by private colleges due to observable measures of college quality? We capture quality with the (log) pupil - teacher ratio, the classical indicator used in the related literature (see Hanushek, 2002), but also control for the (log) number of students in the college and field of study.

Since selection at entry is rare in Italian universities, and mobility is limited, a larger size - conditional on the pupil-teacher ratio - reflects relative demand for college education in the area. We include our selected measure of college quality and college size in the vector $z$ of equation [2] and present the associated estimates in Table 10. We find that the coefficients of the log pupil - teacher ratio and log size attract a negative and positive statistically significant sign respectively.

Table 10. The effects of private college dummies on employment weighted earnings

\begin{tabular}{l|cc}
\hline & & \\
\hline Private college & $.308^{* * *}$ & $.126^{*}$ \\
Log pupil - teacher ratio & $(.057)$ & $(.073)$ \\
& - & $-.241^{* * *}$ \\
Log number students & - & $(.054)$ \\
& & $.164^{* * *}$ \\
Nobs & 279 & $(.051)$ \\
R squared & .312 & 279 \\
\hline
\end{tabular}

Note: see Table 8 . The reduction in the number of observations compared to Table 8 is due to missing information on school quality in some fields of study and universities.

With both the pupil - teacher ratio and the number of students in logs, the associated coefficients can be interpreted as elasticities. Our evidence suggests that a 10 percent reduction in the pupil-teacher ratio should increase 
employment weighted earnings by 2.41 percent. The pupil-teacher ratio and the size of the private universities in our sample are on average 47 and 23 percent lower than in public universities. According to our estimates, these combined differences account for a private college wage premium of 7.6 percent. The additional premium of 12.6 percent associated to private colleges needs to be explained by considering additional factors.

A natural candidate is the presence of network effects. Private universities are valuable non only because of the higher average quality associated to a lower pupil - teacher ratio, but also because they provide access to labour market networks, which are key in the search of good job market opportunities (see Pistaferri, 1999). In a society characterized by relatively limited inter-generational mobility - see Checchi, Ichino and Rustichini, 1999 - we expect the returns from access to these networks to be complementary with the networks associated to privileged parental background.

To investigate this hypothesis, we classify the family background of college graduates in our sample into "poor" and "good", depending on the profession of the father when the surveyed individual was 14, as we did in the previous subsection. We run separate first stage regressions for good and poor background, retrieve the estimated college by field of study effects and replicate the second step estimates in Table 10 separately for each group. The results are reported in Table 11.

Going to a private college matters significantly independently of parental background. However, while the gain from going to a private college is driven by the lower pupil - teacher ratio for students with a "poor" background, it is associated to the private college dummy for students with a "good" background. We interpret this as pointing to complementarity between family and school labour market networks. 
Table 11. The effects of private college dummies on employment weighted earnings

\begin{tabular}{l|cccc}
\hline & $\begin{array}{c}\text { Good } \\
\text { background }\end{array}$ & $\begin{array}{c}\text { Good } \\
\text { background }\end{array}$ & $\begin{array}{c}\text { Poor } \\
\text { background }\end{array}$ & $\begin{array}{c}\text { Poor } \\
\text { background }\end{array}$ \\
\hline Private college & $.355^{* * *}$ & $.348^{* * *}$ & $.276^{* * *}$ & .023 \\
& $(.056)$ & $(.074)$ & $(.099)$ & $(.138)$ \\
Log pupil - teacher ratio & & -.033 & & $-.462^{* * *}$ \\
& & $(.047)$ & & $(.107)$ \\
Log number students & & $.091^{* *}$ & & $.264 * * *$ \\
& & $(.040)$ & & $(.072)$ \\
Nobs & 257 & 257 & & 257 \\
R squared & .325 & .326 & & .401 \\
\hline
\end{tabular}

Note : see Table 8

\section{Conclusions}

Compared to the experience of other developed countries, the system of I talian universities has resisted differentiation. This institutional setup suggests that the college an individual has graduated from - her Alma Mater - should matter little for labour market performance. In this paper, we have used the data from a nationally representative survey of Italian graduates to study whether this implication is correct. We have found that Alma Mater does matter, and that college related differences are large both among regions - the developed North and the under-developed South - and within regions, but perhaps not large enough to trigger substantial mobility flows from poorly performing to better performing institutions.

We have also found that going to a private university - there are a few such institutions in I taly - pays off at least in the early part of a career: the employment weighted college wage gains from going to a private college are close to 18 percent. Only part of this gain can be explained by the fact that private universities have lower pupil - teacher ratios. At least as much depends on other factors, and we speculate that the network effects are particularly important in this perspective. Interestingly, school quality in private colleges matters more for the less privileged who gain access, and less for the privileged, who can combine the informal networks endowed by the family with those provided by the schools. 
It is an open question whether the gains associated to a private university are large enough to compensate the higher tuition costs, and whether they continue as the individual progresses in her labour market history. To answer the second question would require that graduates be reinterviewed significantly later than 3 years after college, as it happens in some countries but not in Italy. 
Data Appendix

\section{Legend - universities}

\begin{tabular}{cl} 
TO & University of Torino \\
TOPOL & Torino Polytechnic \\
VC & University of Vercelli \\
NO & University of Novara \\
AL & University of Alessandria \\
GE & University of Genova \\
CO & University of Como \\
MI STA & University of Milano Statale \\
MI POL & Milan Polytechnic \\
MI BOC & University of Milano Bocconi \\
MICAT & University of Milano Catholic \\
BSCAT & University of Brescia Catholic \\
PC & University of Piacenza \\
ROCAT & University of Rome Catholic \\
MI ULM & University of Milan I ULM \\
MIBIC & University of Milanoi Bicocca \\
BG & University of Bergamo \\
BS & University of Brescia \\
PV & University of Pavia \\
TN & University of Trento \\
VR & University of Verona \\
VE & University of Venezia \\
PD & University of Padova \\
UD & University of Udine \\
TS & University of Trieste \\
PR & University of Parma \\
MO & University of Modena \\
BO & University of Bologna \\
FO & University of Forli \\
FE & University of Ferrara \\
UR & University of Urbino \\
AN & University of Ancona \\
MC & University of Macerata \\
FI & University of Firenze \\
PI & University of Pisa \\
SI & University of Siena \\
PG & University of Perugia \\
VT & University of Viterbo \\
ROSAP & University of Roma Sa pienza \\
ROTOR & University of Roma Tor Vergata \\
ROLUM & University of Roma LUMSA \\
ROLUI & University of Roma LUISS \\
ROTRE & University of Roma Tre \\
CAS & University of Cassino \\
BV & University of Benevento \\
NAFED & University of Napoli Federico II \\
NAPAR & University of Napoli Parthenope \\
NAORI & University of Napoli Orientale \\
NAORS & University of Napoli Sant'Orsola \\
& \\
\hline
\end{tabular}




$\begin{array}{cl}\text { NASEC } & \text { University of Napoli Seconda } \\ \text { SA } & \text { University of Salerno } \\ \text { AQ } & \text { University of Aquila } \\ \text { TE } & \text { University of Teramo } \\ \text { PS } & \text { University of Pescara } \\ \text { CH } & \text { University of Chieti } \\ \text { CB } & \text { University of Campobasso } \\ \text { FG } & \text { University of Foggia } \\ \text { BA } & \text { University of Bari } \\ \text { BAPOL } & \text { Bari Pilytechnic } \\ \text { LE } & \text { University of Lecce } \\ \text { PT } & \text { University of Potenza } \\ \text { CS } & \text { University of Cosenza } \\ \text { CZ } & \text { University of Catanzaro } \\ \text { RC } & \text { University of Reggio Calabria } \\ \text { PA } & \text { University of Palermo } \\ \text { MS } & \text { University of Messina } \\ \text { CT } & \text { University of Catania } \\ \text { CA } & \text { University of Cagliari } \\ \text { SS } & \text { University of Sassari }\end{array}$


Legend - faculties

$$
\begin{aligned}
& \text { AG = agricultural studies } \\
& \text { AR }=\text { architecture } \\
& \text { CH }=\text { chemistry } \\
& \text { EC }=\text { economics } \\
& \text { PH }=\text { pharmacy } \\
& \text { LA }=\text { Law } \\
& \text { EN }=\text { engineering } \\
& \text { HU }=\text { humanities } \\
& \text { FO = foreign languages } \\
& \text { ME = medical studies } \\
& \text { VE = vet studies } \\
& \text { ST = statistics } \\
& \text { SO = sociology } \\
& \text { PS = psychology } \\
& \text { TE }=\text { teachers college } \\
& \text { SC = sciences } \\
& \text { PO = political science }
\end{aligned}
$$




\section{Tables}

Table A1. First step regression for the full sample. Dependent variable: log earnings and probability of employment

\begin{tabular}{|c|c|c|}
\hline & Earnings & Employment \\
\hline Female & $-.108 * * * \quad(.007)$ & $-.274 * * *(.033)$ \\
\hline Graduating marks & $.005 * * *(.0007)$ & $.007 * *(.002)$ \\
\hline Part time job & $-.584 * * * \quad(.016)$ & \\
\hline Graduated one year later than expected & $-.006(.014)$ & $-.008(.072)$ \\
\hline Graduated two years later than expected & $-.036 * *(.016)$ & $-.125(.078)$ \\
\hline $\begin{array}{l}\text { Graduated three years later than } \\
\text { expected } \\
\text { Graduated four years later than expected }\end{array}$ & $\begin{array}{l}-.043 * *(.018) \\
-.061 * * *(.020)\end{array}$ & $\begin{array}{l}-.097(.085) \\
-.156(.091)\end{array}$ \\
\hline $\begin{array}{l}\text { Graduated five or more years later than } \\
\text { expected } \\
\text { Experience }\end{array}$ & $\begin{array}{c}-.079 * * *(.021) \\
.022 *(.011)\end{array}$ & $-.253 * * *(.093)$ \\
\hline Experience squared & $-.0009(.003)$ & \\
\hline Age cohort dummies & Yes & Yes \\
\hline Area dummies & Yes & Yes \\
\hline Number of siblings & Yes & Yes \\
\hline $\begin{array}{l}\text { Interactions of parental education and } \\
\text { occupation }\end{array}$ & Yes & Yes \\
\hline $\begin{array}{l}\text { Interactions of secondary school } \\
\text { graduation marks and type of secondary } \\
\text { school }\end{array}$ & Yes & Yes \\
\hline University by field of study dummies & Yes & Yes \\
\hline Nobs & 10164 & 12868 \\
\hline
\end{tabular}


Table A2. Second step regression. Employment weighted earnings

\begin{tabular}{|c|c|c|c|}
\hline College & Coefficient & College & Coefficient \\
\hline $\mathrm{AL}$ & $.341 * * *(.092)$ & $M C$ & $-.034(.117)$ \\
\hline $\mathrm{AQ}$ & $-.003(.083)$ & MICAT & $.323 * * *(.092)$ \\
\hline BA & $.103(.125)$ & MISTA & $.313^{* * *}(.094)$ \\
\hline BG & $.295^{*}(.167)$ & MO & $.144 *(.082)$ \\
\hline $\mathrm{BO}$ & $.160 *(.091)$ & MS & $-.352 * * *(.118)$ \\
\hline BS & $.097(.092)$ & NAFED & $-.037(.111)$ \\
\hline BSCAT & $.236 * *(.094)$ & NAORI & $.108(.109)$ \\
\hline CA & $-.437 * *(.175)$ & NAORS & $-.069(.142)$ \\
\hline CAS & $.045(.123)$ & PA & $-.279 * *(.141)$ \\
\hline CB & $-.461(.326)$ & PD & $.227 * *(.095)$ \\
\hline CS & $-.158(.116)$ & PG & $.125(.107)$ \\
\hline CT & $-.178(.139)$ & $\mathrm{PI}$ & $.239 * * *(.086)$ \\
\hline $\mathrm{FE}$ & $.209 * *(.090)$ & PR & $.106(.111)$ \\
\hline $\mathrm{FI}$ & $.266 * * *(.092)$ & PS & $-.097(.094)$ \\
\hline GE & $.003(.110)$ & PV & $.247 * *(.099)$ \\
\hline LE & $-.045(.129)$ & ROLUI & $.288 * *(.116)$ \\
\hline ROTOR & $-.051(.146)$ & SI & $.158(.117)$ \\
\hline ROTRE & $.075(.099)$ & SS & $.035(.102)$ \\
\hline SA & $-.273^{* *}(.115)$ & $\mathrm{TN}$ & $.119(.083)$ \\
\hline TO & $.372 * * *(.096)$ & TS & $.294 * *(.114)$ \\
\hline UD & $.239 * *(.115)$ & UR & $.084(.111)$ \\
\hline VE & $.151 *(.077)$ & VR & $.342 * * *(.099)$ \\
\hline
\end{tabular}

Note: Roma La Sapienza in the constant term. 


\section{References}

Arum, R., Gamoran, A., and Shavit, Y., 2004, Inclusion and diversion in higher education: expansion, differentiation, and market structure in fifteen countries, mimeo.

Black and Smith, 2004, How robust is the evidence on the effects of college quality? Evidence from Matching, Journal of Econometrics

Brand and Halaby, 2003, Regression and matching estimates of the effects of elite college attendance on labor market outcomes, University of Wisconsin Madison

Card, D. e Krueger, A., 1990, Does school quality matter? Returns to education and the characteristics of public schools in the United States, Journal of Political Economy, 1-39.

Catalano and Fiegna, 2003, La valutazione del costo degli studi universitari in Italia, II Mulino.

Checchi, D., Ichino, A. and Rustichini, A., 1999, More equal but less mobile? Intergenerational mobility and inequality in Italy and in the US. Journal of Public Economics, 74: 351-393

Chevalier and Gonlon, 2003, Does it pay to attend a prestigious university?, CEP Discussion Paper, LSE

Perotti, 2004, The Italian University System: Rules vs. Incentives, paper presented at the Conference "Monitoring Italy".

Pistaferri, L., 1999, Informal Networks in the Italian Labour Market, Giornale degli Economisti e Annali di Economia, 58, 355-375.

Silvestri, P., Catalano, G. and Bevilacqua, C., 1996, Le tasse universitarie e gli interventi per il diritto allo studio, IRES Toscana.

Warren, J., Hauser R. and Sheridan, J., 2002, Occupational attainment across the life course, American Sociological Review, 67, 432-455 